\title{
SEJARAH MASUKNYA ISLAM DI MAJENE History of the Entry of Islam in Majene
}

\author{
Oleh: Abd. Shadiq Kawu* \\ * Peneliti pada Balai Penelitian dan Pengembangan Agama Makassar \\ Kantor: Jl. A.P. Pettarani No. 72 Makassar \\ E-mail: shadiq kalvii ffgmail.com
}

\begin{abstract}
Abstrak
Penelitian ini menggunakan pendekatan sejarah sosial. Sebuah pendekatan yang menekankan pada aspek perubahan yang terjadi sebagai akibat pertemuan Islam dengan masyarakat lokal, masyarakat Mandar Majene (Kerajaan Banggae). Penggalian data lapangan menggunakan wawancara mendalam kepada ahli sejarah Mandar, dan dengan dukimgan literatur serta naskah-naskah lontaraq yang tersedia. Hasil penelitian menunjukkan bahwa Islam masuk ke Majene (Banggae) pada abad XVI dibawa oleh Syekh Abdul Mannan atau Tosalama di Salabose. Penyebaran Islam jaya di zaman pemerintahan I Moro Daengta Masigi. Perubahan yang paling mendasar akibat persentuhan dengan Islam adalah lata cara peralihan kekuasaanyang lebih terbuka dan menitikberatkan kepada kemampuan bukan turunan semata. Pengarah Islam juga terlihat clalam tradisi masyarakat yang masih dapat ditemui sekarang.
\end{abstract}

Kata Kunci: Sejarah Islam, Perubahan, Kerajaan Banggae.

\section{Abstract}

This study uses the social history approach. An approach that emphasizes the aspects of the changes that occur as a result of the meeting of Islam with local communities, Mandar community, Majene (Banggae Kingdom). Field data collection using in-depth interviews to historians Mandar, and with the support of literature and manuscripts lontaraq available. The results show that Islam entered the Majene (Banggae) in the sixteenth century brought about by Sheikh Abdul Mannan or Tosalama in Salabose. The spread of Islam was very advanced in the reign of I Daengta Masigi Moro. The most fundamental changes due to contiguity with Islam is an ordinance of the transfer ofpower that is more open andfocused on skills rather than merely derivative. Islamic influence is also visible in the tradition of that society can still befound today.

Keywords: Islamic History, Change, Kingdom Banggae.

\section{PENDAHULUAN}

$\mathrm{I}$

lam masuk ke Indonesia secara bergelombang. Demikian pula, masuknya Islam di kerajaankerajaan di nusantara yang kemudian - mproklamirkan did bahwa Islam sebagai agama ni, datangnya tidak bersamaan. Namun, agama Islam masuk ke kerajaan-kerajaan di nusantara berdasarkan atas kondisi situasi politik dan sosial budaya. ${ }^{1}$

Masuknya Islam ke nusantara melalui dua tahap. Tahap pertama berupa perkenalan masyarakat npat dengan Islam yang terjadi sekitar abad ke-
VII dan abad ke-VIII melalui pedagang-pedagang muslim yang melakukan Iawatan ke nusantara. Namun, pada tahap ini terdapat silang pendapat beberapa ahli. Ahli pertama mengatakan bahwa pedagang-pedagang yang berasal dari Arab sudah ada sejak abad VII. Mereka merujuk pada tafsiran Ta-shi dalam berita Cina.

Sedangkan sebagian ahli lainnya, termasuk C. Snouck Hurgronje, seorang misionoris Belanda, berpendapat. bukan pedagang-pedagang langsung Arab yang pertama kali menyebarkan Islam melainkan pedagang Islam yang berasal dari Gujarat (India). Persia. Arab, clan Cina. Alasan Hurgronje adalah

Sofia Rangkuti-Hasibuan. 2002. Manusia dan Kebudayaan di Indonesia. Teori dan Konsep. Jakarta. Cetakan pertama. Dian Rakyat. h. 73 . 
adanya temuan batu-batu nisan dari Samudera Pasai bertuliskan nama Sultan Malik as-Saleh pada 1927 Masehi dan beberapa nisan lainnya dari abad-abad berikutnya yang terbuat dari manner buatan pabrik di Cambai, Gujarat.

Sementara tahap kedua adalah tahap pengembangan dan penyebaran Islam di nusantara. Pada tahap ini, menurut Nugroho Notosusanto bentuk kerajaan bercorak Islam pertama adalah Samudera Pasai dan Perlakdi pesisirTimur Aceh pada abad XIII. ${ }^{3}$ Hal ini berdasarkan keterangan seorang pedagang dan penjelajah Venesia, Eropa, Marco Polo, yang singgah ke Sumatera dalam perjalanan pulang menuju negeri asalnya pada $1292 .^{+}$

Masuknya Islam di kerajaan-kerajaan Tanah Mandarjuga tidak beragam. Menurut Ibrahim Abbas, Islam pertama kali masuk ke Tanah Mandar pada abad XVI dan dibavva oleh para penganjur dari tanah seberang yang disebut oleh penduduk lokal sebagai wali. Sedangkan budayawan Mandar, A.M. Mandra, mengatakan, Islam mulai masuk pada abad XVII di Balanipa yaitu pada zaman Kerajaan Balanipa IV, Kanna I Pattang alias Daetta (putra Tonajalloq) dan kemudian di Pamboang pada 1665 di zaman Raja Tomatindo di Agamana. ${ }^{6}$

Sejak abad XVI, Tanah Mandar memiliki 14 kerajaan', dengan masing-masing menjalankan pemerintahan secara otonomi. Untuk menjalankan strategi melawan penjajah, ketujuh kerajaan tersebut bersatu dalam satu organisasi ketatanegaraan berbentuk federasi yang diberi nama Pitu Ba'bana Binanga atau dalam bahasa Mandarnya Tujuh Muara Sungai. Ketujuh kerajaan itu adalah Balanipa, Sendana, Banggae, Pamboang, Tappalang, Mamuju, dan Binuang. ${ }^{8}$ Selanjutnya, tujuh kerajaan ini mengadakan lagi perjanjian dengan tujuh kerajaan yang berada di wilayah pegunungan yang dinamakan Pitu Ulunna
Salu (Tujuh Hulu Sungai). Ketujuh kerajaan tersebut adalah Rantebulahan, Aralle, Mambi, Bambang, Messawa, Tabulahan, dan Matangnga.

Kendati begitu, penelitian ini tidak mendalami masuknya Islam pada semua kerajaan di Tanah Mandar. Penelitian ini hanya fokus kepada satu kerajaan di Tanah Mandar, yaitu Kerajaan Banggae, yang wilayah administrasinya berada di Kabupaten Majene, Provinsi Sulawesi Barat. Islam masuk dan akhirnya berkembang pesat ketika Kerajaan Banggae dipimpin oleh seorang mara'dia (raja Banggae III) bernama I Moro, bergelar Daengta di Masigi pada abad XVI. Pada masa mara 'dia inilah, Islam dijadikan agama resmi.

Mengacu pada pemaparan terkait dengan kondisi obyektif sejarah lokal dan nasional yang mengalami ketimpampangan antara dassein dan dassolen sebagaimana yang dideskripsikan di atas, maka penelitian akan fokus pada beberapa masalah penelitian adalah Bagaimana konstruksi sejarah kerajaan lokal berdasarkan fakta dan peninggalan sejarah yang ada? Bagaimana proses islamisasi pada domain sosial-politik kerajaan lokal tersebut? Dan Bagaimana dampak perubahan sosial-politik pasca proses islamisasi dalam domain kerajaan lokal?

\section{HASIL PENELITIAN}

\section{Asal-usul Nama Majene}

Dari sudut pandang sejarah, daerah Majene tidak dapat dipisahkan dengan daerah yang dihuni etnis Mandar dan secara keseluruhan meliputi lima kabupaten di Provinsi Sulawesi Barat yaitu, Majene, Mamuju, Mamuju Utara, Polewali Mandar, dan Mamasa. Di daerah ini, sejak abad XVI, terdapat tujuh kerajaan yang terletak di pesisir pantai yang dikenal dengan nama Pitu Ba 'bana Binanga,' yang secara harfiah berarti Tujuh Kerajaan di Muara Sungai atau

Ibid., h. 74.

Samudra Pasai dan Perlak sekarang ini terletak di Kabupaten Lhok Sheumawe atau Aceh utara.

Sofia Rangkuti. (No. 1).. op.cit.. h. 75 .

Ibrahim Abbas. 2000. Pendekalan Budaya Mandar. Makassar. UD Hijrah Grafika, him. 137.

A.M Mandra. 2005. To Manurung di Mandar dalam Tinjauan Syarial Islam. Yayasan Saq-Adawang Sendana Majene bekerjasama dengan Pemerintah Kabupaten Majene. h. 48

Muh. Idham Khalid Bodi dan Ulfiani Rahman. 2006. Bahasa Busana Mandar. Tangerang. Penerbit Nuqtah. h. 25.

"Ibid., h. 26.

Darmawan Mas'ud Rahman mengatakan, Pitu Ba'bana Binanga adalah nama dari persekutuan tujuh negeri yang disebut tujuh amara'diangang (monastic) yang terbentuk sekitar abad XVI sampai XIX masehi. Kini, Mamuju dan Tappalang masuk ke dalam wilayah administratif Kabupaten Mamuju, sedangkan Pamboang, Sendana, dan Banggae masuk wilayah Kabupaten Majene. Sementara Balanipa dan Binuang menjadi administratif wilayah Kabupaten Polewali Mandar. Ketiga kabupaten tersebut di atas sebelumnya terafiliasi dalam Afdeling Binuang menjadi administratif wilayah Kabupaten Polewali Mandar. Ketiga kabupaten tersebut di atas sebelumnya terafiliasi dalam Afdeling
Mandar. yang pusat pemerintahannya berpusat di Majene sesuai bentukan Pemerintah Hindia Belanda I.ihat. Muhammad Rais. 2008 Etika Mandar. yang pusat pemerintahannya berpusat di Majene sesuai bentukan Pemerintah Hindia Belanda I.ihat. Muhammad Rais. 2008
Bisnis Wirausaha Majene-Mandar. dalam Disertasi. Makassar. Program Pascasarjana Universitas Hasanuddin, h. 42. tidak diterbitkan. 
tHjuh kerajaan di bagian pesisirpantai daerah Mandar. Kemjuh kerajaan tersebut adalah Balanipa. Banggae, Pamboang. Sendana, Tappalang, Mamuju, dan Binuang. Kerajaan Sendana dan Pamboang masuk ke diiani wilayah Majene.

anjutnya, tujuh kerajaan lain, yangjuga berada dETanah Mandar dan terletak di bagian pegunungan, nukjuga serikat konfederasi yangdiberi nama lunna Salit (Tujuh Kerajaan di Hulu Sungai JBau tujuh kerajaan di bagian pegunungan daerah - ::- Sebagai kepala pemerintahan masing-masing kerajaan dipimpin oleh seorang raja bergelar Mara dia. ${ }^{10}$ Raja diangkat berdasarkan permufakatan - ' - Aangsawan dengan hadat atau perwakilan rakvat. Pelantikan seorang raja dinamakan dtparakkai. Salah satu acara terpenting adalah ". . - an lisan di depan unuim (assitalliang) antara lajayang dilantik dengan salah seorang anggota hadat lertentu yang mewakili rakyatnya. Pembentukan pcrserikatan Pitu Ba 'bana Binanga dan Pitu Ulunna Jkrfv diprakarsai oleh seorang raja dari Kerajaan >a bernama Tomepayung."

Lahirnya Majene sebagai suatu wilayah belum secara pasti hingga kini. Secara historis belum ditemukan tanggal, bulan, dan tahun berapa - - terbentuk secara resmi sebagai suatu milayah.^Namun, untuk mengetahui kapan dan siapa

- . ih memberikan nama Majene, dapat ditelusuri -elalui lontara, seperti dikemukakan Ahmad dan Marjanah. yaitu:

Lontara Tappalang. Lontara ini menyebutkan, Gubernamen Nederlansche Indie berangkat

ke Tappalang melalui Majene, Pamboang, dan ndana, pada Senin, 31 Oktober 1892. Keterangan ini didukung pula oleh suatu tulisan yang dimuat majalah terbitan Belanda, bii Brijdragen toot de taal, land en Volkenkunde Van Nederlanche Mandarsche Indie dengan jitdiil tulisan "Madedeelingen : - '. 'tende Enige Mandarshe Landscappen" i tatan-catatan tentang Beberapa Daerah idar. yang salah satu sub judulnya bertuliskan kata "Majene". Naskah ini berasal dari Leiden terjemahan Dr. Robert $L$. Welsch, tahun 1907).

2. Lontara Bilang Raja Gowa dan Tallo, yang menyebutkan, antara lain:

a. "Hera 1659, 1 Setemberek, 15 Dolohaji, Bangngi Sanning Namate Karaeng Balangbaru I rawa ri Majeknek. " Artinya: Tahun 1659, 1 September, 15 Zulhajji, malam Sening meninggalnya Karaeng Balangbaru di Majene.

b. "Hera 1665, 26 Abarele, 10 Sawwalak, alio Ahak. Naniliungan Karaeng Majeknek nanipuliang Karaeng Bungaya. " Artinya: Tahun 1665, 26 April, 10 Syawal, hari Minggu, Raja Majene dikepung dan Karaeng Bungaya dibalaskan dendamnya.

3. Lontara Tallo (I Macang KebokaJ. Dalam lontara ini disebutkan, Raja Gowa Karaeng Tomapa 'risi' Kallonna, yang menjabat tahun 1500, memerintahkan Raja Tallo Mangkubumi Kerajaan Gowa Imappatakakan Tana Karaeng Pattingalloang, dengan mengatakan, " Naongko Maeri Majeknek Na Nupajului Sari'battannu I Rawa Na Nuropu Tidunga. " Artinya: Turunlah ke Majene, temui saudaramu di bawah dan hancitrkan Tidung.

Namun, kisah yang terdapat dalam lontara tersebut belum sepenuhnya mengidentifikasikan apa makna Majene sebenarnya. Dari beberapa informan mengatakan, penamaan Majene itu sebenarnya pemberian Belanda yang saat itu datang ke daerah ini. Tradisi lisan ini kemudian berkembang dan dipercaya oleh masyarakat hinggakini. Hanya, tradisi lisan ini pun terdapat beberapa versi. Versi pertama, saat orang Belanda melabuhkan perahunya di pantai, ia menanyakan kepada penduduk lokal yang tengah mengambil wudhu di pinggir pantai. Orang Belanda itu bertanya dengan menggunakan bahasa Belanda. Karenatidak mengerti pertanyaan tersebut, makayang ditanya tadi menjawab seadanya. Kemungkinan,

J Salam. 2005. "Nilai-Nilai Budaya yang terkandung dalam Upacara Daur Hidup pada Masyarakat Mandar di Banggae Kabupaten pae". dalam Laporan Hasil Penelitian Sejarah dan S'ilai Tradisional Sulawesi Selatan dan Tenggara. Makassar: Balai Kajian Sejarah dan - Tradisional. h. 191-192.

Muh. Idham Khalid Bodi \& Ulfiani Rahman. 2006. op.cil, h. 25-26.

Wauancarai dengan Kepala Museum Mandar/Majcne. Ahmad Hasan, di Majene pada 21 April 2010

Ahm.'.J \& Marjanah. 2007. Sejarah dan Kebudayaan Mandar ./did I. Sejarah Mandar dan Sejarah Perjitangan Bangsa di Kabupaten feme Baas Pendidikan dan Kebudayaan Kabupaten Majene Bidang Binmudorabud Seksi Kebudayaan. h. 7. 
penduduk lokal tersebut menduga bahwa orang Belanda itu menanyakan apayang sedang ia lakukan. Maka, iapun menjawab," "Manje 'ne" (dalam bahasa Mandar berarti berwudhu)." Alhasil, mulai saat itu dan sampai saat ini, daerah ini dikenal oleh pendatang luar dengan nama Majene. Versi lain tetapi masih berkaitan dengan Belanda adalah lokasi terjadinya dialog. Ada yang mengatakan kalau orang Belanda bertanya kepada penduduk lokal itu bukan di pinggir pantai melainkan di masjid. Sedangkan versi lain lagi menyebutkan, orang yang datang pada saat itu bukanlah orang Belanda melainkan orang Melayu. Mereka datang ke Majene/Tanah Mandar untuk bemiaga. Kisahnyajuga sama yaitu menanyakan daerah yang didatanginya kepada penduduk setempat dengan menggunakan bahasa asalnya (Melayu).

\section{Islamisasi di Kerajaan Banggae}

\section{Awal Perkembangan}

Mendahului penulisan mengenai Islamisasi di Kerajaan Banggae, perlu dikemukakan proses terbentuknya kelompok masyarakat Banggae. Dalam tradisi lisan dikatakan, pada mulanya masyarakat Banggae menetap di pegunungan dan perbukitan di Salogang, Poralle, Totoli, Ambe Allu, Mawasa, Lambe' Susu, dan Nairn Indu'. Setiap kelompok dipimpin seorang bergelar Tomatua. Pada proses selanjutnya timbul kekacauan dan peperangan antarkelompok masyarakat yang dikenal "Siande-ande Baui Pa'banua"". Akhirnya Tomatua Salogang melakukan inisiatif perdamaian dengan mengundang para Tomatua bermusyawarah di Baruga.

Inti pertemuan disepakati bahwa peperangan antarkelompok masyarakat harus segera dihentikan, dan ketujuh kelompok masyarakat dilebur dalam satu kepemimpinan. Namun, di antara ke tujuh Tomatua tersebut tidak ada yang sanggup memimpin. Akhirnya ketujuh Tomatua mengetahui bahwa di bagian utara telah turun dari langit seorang perempuan (Tomanurung) yang kemudian diperistrikan oleh seorang bergelar "Pattori Bunga". Ketujuh Tomatua menghadap Tomanurung dan memintanya agar menyelesaikan pennusuhan ketujuh Tomatua dan mengangkat Tomanurung sebagai pemimpinnya. Tomanurung menerima sebagai pemimpin dan diangkat sebagai "Indo Banua".
Namun, Tomanurung tidak langsung menyetujui permintaan tersebut. Ia kemudian berkata:

Mua' melo 7 nnipa 'dai siande-ande ban di parammu pa'banua, ammungi tammuba' barang tallv passai pasang pole dilangi'iamo disa'bi sipatau, sitaiyang acoangngang tassitaiang adhaeang, annami soei saoemn uposoei soeku.

Artinya:

Jika serins ingin menghentikan pertikaian dan peperangan di antara kalian, maka kalian harus memegang leguh pesan dari langit, yakni saling menghargai di antara kalian, saling menuntun kepada kebaikan dan saling mencegah kepada keburukan, dan kalian tidak boleh mencampuri urusan kelompok masing-masing.

Apa yang disampaikan Tomanurung kepada tujuh Tomatua itu mengandung makna yang sangat mendalam, setidaknya, mengajarkan bahwa apapun alasannya, permusuhan dan peperangan itu tidak pernah dibenarkan karena pasti akan mendatangkan kerugian di kedua belah pihak. Karena itu, Tomanurung meminta semua manusia untuk saling menghormati dan menghargai, serta tidak boleh mencampuri urusan orang lain. Terjadinya beberapa konflik di Indonesia tak lain juga disebabkan oleh tidak adanya rasa saling menghormati dan menghargai antarsesama. Maksudnya, masalah yang sepele bisa saja menjadi besar apabila ada oknum-oknum yang sengaja menghasut dan menyulut pertikaian.

Lalu, bagaimana tanggapan ketujuh Tomatua mendengar pesan dari Tomanurung? Mereka pun berkata:

nitarimai anna' niammungi tanniba 'barang pasang pole di langi'anna'nipitaid diolo ala'biranna Tomanurung nanianna Indo Banua."

Artinya:

Kami menerima dan akan tetap berpegang teguh kepada pesan dari langit. Karena itu, kami meminta Tomanurung sebagai pemimpin negeri kami.

Sebagai pernyataan rasa syukur, ketujuh Tomatua bersama masyarakatnya melaksanakan upacara di Pattu'duang" selama tujuh hari tujuh malam di hadapan Tomanurung, selanjutnya diberi gelar "Tomanurung di Pattu'duang'*. ${ }^{18}$

Berdasarkan lontara dan tradisi lisan. penamaan Majene itu diperkirakan sejak niasa Pemerintahan Raja Govva Tomapa'risi'Kallonna pada 1500 Masehi.

Ibid., h. 29.

" Ibid.

"Lokasi Palm duang berada di wilayah Kelurahan Baruga Dhua. sebelah utara berbatasan dengan Kabupaten Polewali Mandar. di sebelah timur berbatasan dengan Kecaniatan Pamboang.

Pada prinsipnya, tradisi lisan yang bidup dalam masyarakat mempunyai kemiripan. Intinya, secara keseluruhan bermuara pada proses terbentuknya kerajaan-kerajaan di daerah Majene. 
Seperti disebutkan sebelumnya, Banggae (Majene) -mpafcan kerajaan yang tidak dapat dipisahkan atau

- kedudukan persekutuan Pitu Ba'bana $\mathrm{h} \mathrm{M}^{\wedge} \mathbf{j} \mathbf{i} \mathbf{i} \mathbf{u} \mathbf{j} \mathbf{u} \mathbf{h}$ muara sungai)yaitu Kerajaan Balanipa.

B. agae. Pamboang, Tappalang, Mamuju, dan kerajaan-kerajaan tertua yang pernah -ribnndi kawasan Mandar di atastelah menampilkan - " - r_ _an interaksi yang saling memengaruhi ha saJing ketergantungan antara berbagai aspek Kftadupan kerajaan pada masa itu.

Dalam tradisi lisan (oral tradition) Banggae - - - rahwa setelah Tomanurung kembali ke "dalui tujuh keturunan Tomanurung neanimdian diangkat sebagai pemimpin bergelar hmaluika dalam setiap kelompok masyarakat di liigj ie. Dengan demikian, yang sebelumnya rainiBpin kelompok masyarakat bergelar Toinatua KoJui kepada kepemimpinan seorang Towakaka ami Jdmakaka Salogang. Poralle, Totoli, Ambe Allu, 1 - ij i. Lambe" Susu, dan Naun InduV

Dalam lontara Banggae dan Totoli dinyatakan - fcwa kedatangan panglima perang Kerajaan HBjapohh bernama Wungu yangjuga kemenakan dari iiapahit. orang Mandar menyebutnya Topole.ndatang)." bersama pengikutnya di pantai I-wr" mempunyai peran penting dalam proses «st:oentukan Kerajaan Banggae. Topole-pole - gfcwlap Tomakaka Mawasa dan diterima menetap Adanya perselisihan antara Tomakaka -fcr*i>a dengan Tomakaka Poralle menyangkut - aeaeketaan tapal batas kedua wilayah tersebut telah 12 Topole-pole membantu menyelea lannx. a. Topole-pole bersama seorang pengikutnya c-ingkat ke Poralle dan setibanya di Poralle sedang t-iangsung permainan sepak raga. Topole-pole diajak enmain dengan Tomakaka Poralle. Kepintarannya -• ain. Topole-pole dikagumi Tomakaka dan rakat Poralle. Setelah mengetahui maksud dan -an Topole-pole, Tomakaka Poralle menyambut baik - e'esaian sengketa batas dengan Mawasa. Selama le-i-etap di Poralle, Topole-pole menaruh hati dengan putri Tomakaka Poralle yang bergelar tomarruparupa bulawang dan keduanya dikawinkan oleh Tomakaka dan menetap di Poralle."

Setelah lama menunggu berita dari Topole-pole tentang penyelesaian sengketa batas di Poralle. maka Tomakaka Mawasa beserta pengikutnya berangkat ke Poralle. Setibanya di Poralle, Tomakaka Mawasa disambut Topole-pole beserta Tomakaka Poralle. Dalam pertemuan tersebut, Tomakaka Mawasa menyampaikan maksud kedatangannya bahwa orangorang Poralle telah membuka lahan barn dalam wilayah Mawasa. Selanjutnya Tomakaka Poralle bersedia menghentikan dan mengembalikan kembali lahan tersebut kepada Mawasa. Kemudian disepakati bahwa penggunaan lahan tersebut diserahkan kepada Topolepole untuk mengurusnya. Berangkat dari peristiwa ini, maka setiap terjadi permasalahan baik yang dialami Mawasa maupun Poralle meminta pertimbangan dari Topole-pole $\quad$. $^{2 z}$

Kembali kepada kehidupan Topole-pole, dari hasil perkawinannya dengan Tomarrupa-rupa bulawang telah melahirkan dua putrayaitu I Salabose Daengta di Poralle dan I Banggae. Setelah kedua putranya dewasa, 1 Salabose Daeng ta di Poralle kawin dengan I Manyambungi (putri Raja Balanipake-2) ${ }^{23}$ dan $f$ Banggae mengawini putri I PuangNaung Indu' yang kelak menurunkan keturunan Pa'bicara Banggae. ${ }^{24}$

Ramainya jalur pelayaran dan perdagangan di kawasan Teluk Mandar telah menarik orang-orang Tidung melakukan perompakan terhadap perahuperahu yang melalui jalur tersebut. Keberadaan para peronrpak Tidung menjadi ancaman tersendiri para Tomaka, selanjutnya mereka musyawarah dan disepakati mengangkat I Salabose Daeng ta di Poralle dan I Banggae untuk mengusir para perompak Tidung di kawasan Teluk Mandar. Demikian pula laporan dari para pelaut, melalui jalur Teluk Mandar, kepada Raja Gowa yang telah menggangu jalur pelayaran dan perdagangan Gowa-Tallo menyebabkan Gowa-Tallo mengutus pasukannya ke Mandar untuk membasmi perompak Tidung. Keberadaan pasukan Gowa-Tallo

-iah Tomanurung melahirkan tujuh anak laki-laki. ia kembali ke langit. Kemudian, para Tomatua menghadap kepada suami Patlora Bunga, untuk menggantikan posisi islrinya sebagai Indo Banna telapi ditolak oleh Pattora Bunga. Meski begitu, ia ilusi bagaimana kalau ketujuh putranya saja yang diangkat sebagai pemimpin kelompok mereka. Dan. tawaran ini pun disepakati IA fcchijuh Tonialua dan masing-nlasing diberi gelar "Tomakaka" di depan namanya Lihat; Ahmad \& Marjanah. 2007. ibid. h. 30-31.

- Muhammad Rais. 2008. op.cit., h 36.

- \hmad \& Marjanah. 2007. op.cit. h 45-47.

$=$ Ibid. him. 48-49.

--->il perkawinannya melahirkan einpal keturunan yaitu Daeng ta I Talli. 1 Bali Baru'. Daeng ta I Puja. dan Daeng ta I Milanto. 
bersama-sama pasukan I Salabose Daeng ta di Poralle dan I Banggae berhasil mengusir para perompak Tidung di Teluk Mandar. Setelah kejadian tersebut, I Salabose Daeng ta di Poralle diangkat sebagai totongang loa yang bertugas sebagai panglima perang para tomakaka dan menyelesaikan pertnusuhan antara kelompok masyarakat. ${ }^{25}$

Setelah I Salabose Daeng tadi Poralle meninggal, kemudian putranya Daengta I Milanto diangkat sebagai totongang loa oleh para tomakaka menggantikan kedudukan ayahnya Daeng ta I Milanto kemudian mengawini putri Tomakaka Totoli, dan dari perkawinannya mendapatkan keturunan putra yang dikenal dengan nama I Moro Daeng ta di Masigi. ${ }^{26}$ Selanjutnya, I Moro Daengta di Masigi diangkat sebagai mara'dia (raja) Banggae melalui musyawarah Andongguru Tonggang Loa \{Mara 'dia Tandey, Pa 'bicaraBanggae (mewakili Totoli dan Lambe'Allu), Tomakaka Salogang, dan Tomakaka Mawasa.

\section{Penyebaran Islam di Kerajaan Banggae}

Masuknya Islam di Kerajaan Majene/Banggae, Sendana, Pamboang, dan Malunda, melalui dua tahapan. Tahap pertama terjadi pada abad XV yaitu melalui pedagang-pedagang muslim yang berdagang di daerah ini. Lewat merekalah, Islam kemudian diperkenalkan kepada penduduk setempat. Hanya saja, metode ini kurang efektif karena tujuan utama para pedagang muslim tersebut adalah ekonomi dan bukan menyiarkan agama Islam.

Namun, sikap yang ditunjukkan para pedagang muslim dengan cara menghargai tradisi dan menghormati raja akhirnya mendapat simpati raja, sehingga pihak kerajaan pun memberikan perlindungan dan fasilitas kepada mereka. Meski begitu, belum terjadi konversi di pihak kerajaan maupun penduduk lokal. Pada tahapan kedua, yaitu abad XVI-XVII, barulah terjadi kontak antara penyebar agama Islam dengan masyarakat. Berbeda dengan tahapan pertama, penganjur agama Islam kali ini bukan berasal dari pedagang melainkan mereka betul-betul datang dengan maksud untuk menyebarkan agama Islam. ${ }^{28}$
Pada periode ini, terjadi perubahan penting dalam kehidupan masyarakat Banggae, terutama setelah masuknya Islam di dalam kerajaan pada abad XVI. Mara'dia I Moro Daeng ta di Masigi merupakan peletak dasar Islamisasi di Banggae. Sebelum I Moro diangkat sebagai mora 'dia, masa mudanya menunjukkan petualangan dengan melakukan aktifitas pelayaran dan perdagangan, sehingga masyarakat menyebutnya anakodha bisa (nakhoda sakti). ${ }^{29}$ Dalam pelayarannya ke Jawa Timur, I Moro bertemu Syekh Abdul Mannan dan kemudian menjadi teman seperguruan. Kemudian, I Moro mengajak Syekh Abdul Mannan beserta pengikutnya ke Banggae.

Awal masuknya Islam di Tanah Mandar kerapkali diwarnai cerita-cerita mitos. Namun, hal tersebut tidak bisa diartikan secara tekstual, melainkan harus diberi makna tentang kehebatan dan kelebihan pembawa Islam pertama dibanding rata-rata penduduk setempat. ${ }^{30}$ Seperti, misalnya, Syekh Abdul Mannan setibanya di Banggae mengajak Tomakaka Poralle memeluk Islam. Namun, Tomakaka Poralle tidak langsung menerima tawaran itu. Ia pun memberi syarat yaitu bersedia memeluk Islam asalkan Syekh Abdul Mannan mampu mencabut keris miliknya dari sarungnya. Ternyata, Syekh Abdul Mannan dapat mengeluarkan keris itu dari sarungnya, dan sejak saat itulah Tomakaka Poralle memeluk Islam. Setelah Tomakaka Poralle memeluk Islam, lambat laun rakyatnya mulai memeluk Islam. ${ }^{31}$

Terdapat beberapa versi mengenai proses masuknya Islam di Banggae. Namun, semuanya itu menunjuk pada satu nama tokoh sentral yakni Syekh Abdul Mannan. Darmawan Masud Rahman, seperti dikutip Muhammad Rais, mengatakan, Abdurrahim Kamaluddin (penganjur Islam di Balanipa), terpaksa tidak melanjutkan perjalanan dakwahnya ke Majene (hanya berjarak $7 \mathrm{Km}$ dari Balanipa) karena dalam waktu bersamaan Abdul Mannan juga tengah menyiarkan Islam di daerah tersebut. Ibrahim (2000: 138-139) pun demikian. Menurutnya, penganjur agama Islam di Kerajaan Banggae adalah Syekh Abdul Mannan yang bergelar Tosalama di Salabose.

Ibid., h. 50-51.

Ibid. h. 52

Ibid. h. 58.

Ibid., h 72-74

Ibid. h. 53

"'Masyarakat tradisional yang masih kental dengan kepercayaan ariimisme dan dinamisme tentu sangat mempercayai segala sesuatu yang berkailan dengan mistik bercampur mitos. Pandangan ini juga sesuai pendapat Hamka bahwa kaum sufi lebih toleran terhadap kebiasaankebiasan atapun adat istiadat yang dianut oleh masyarakat Karena itu kaum sufi mempunyai peranan penting dalam islamisasi pertama di

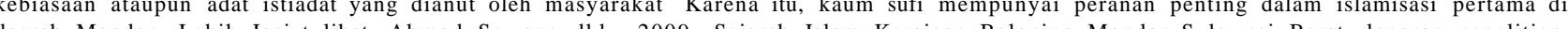
daerah Mandar. Lebih lanjut lihat, Ahmad Sewang dkk. 2009. Sejarah Islam Kerajaan Balanipa Mandar Sulawesi Barat, laporan penelitian.
disampaikan pada seminar hasil penelitian di Puslitbang Lektur Keagamaan Balitbang Jakarta, h. 1.

Ahmad dan Marjanah 2007. op.cit, h. 76. 
la leluasa menyiarkan Islam sampai ke Totoli karena i mendapat restn dari Tomatindo di Masigi (I More Daeng ta di Masigi) selaku Mara 'dia Banggae, kala itu.

Dalam tradisi lisan lain, pada masa kekuasaan Raja Banggae 11, Daeng ta 1 Milanto, ia memerintahkan putranya I Moro untuk melakukan pelayaran dan perdagangan khususnya di Jawa. Dalam pelayarannya

but. 1 Moro menemukan sebuah peti yang berisi laki-Iaki dan kemudian melanjutkan perjalanannya ""enuju Pelabuhan Paku, Jawa Timur. Di Paku, 1 Moro endapatkan infomiasi kalau bayi tersebut adalah putra Maulana Ishak (penyebar agama Islam di Jawa). yang itu dalam pelayaran ke Samudera Pasai. Aceh.

Tanpa membuang waktu, I Moro lalu melanjutkan pelayarannya ke Samudera Pasai untuk mencari ayah

itu. Sayang, setelah tiba di Samudera Pasai, Maulana Ishak ternyata sudah tidak ada di situ dan isarkan informasi masyarakat setempat ia dalam peijalanan ke Mekkah. Kemudian, 1 Moro melanjutkan a larannya ke Mekkah. Di sinilah I Moro bertemu Maulana Ishak dan menyerahkan putranya. Setelah nan tersebut, 1 Moro kembali ke Jawa dan

i perjalanannya mampir ke Samudera Pasai, yang a saat itu Islam telah menjadi agama resmi kerajaan. ketika menetap di Samudera Pasai, I Moro punya

" an terhadap ajaran Islam. Dari sinilah awal rikannya terhadap Islam. Meski begitu, ia mudian melanjutkan pelayarannya ke Jawa Timur. i di tempat inilah I Moro memeluk Islam di bawah m seorang ulama Gresik. ${ }^{3}--$

Tidak diketahui secara pasti berapa lama I Moro ilami Islam di Gresik, Jawa Timur. Begitu pula, diketahui siapa iiama guru yang pertama kali g-Islamkan atau mengajarkan mengucapkan "at Syahadat kepada I Moro. Namun, ada versi g mengatakan, orang yang meng-Islamkan I Moro iigus guru spiritualnya adalah Syekh Abdul Man-

Hanya, versi ini berbeda dengan apa yang kan Ahmad Hasan. Menurut budayawan Majene

o setelah kembali ke daerahnya dari pelayaran memeluk Agama Islam, dan atas saran gurunya : "iiinta menyebarkan agama barunya itu ke ;n a. Namun, I Moro belum berani menyebarkan sendirian. Karena itu. ia pun meminta saran nya untuk dicarikan teman yang dapat itunya untuk menyebarkan Islam di daerahnya. ian. gurunya merekomendasikan enam orang. termasuk di antaranya Syekh Abdul Mannan. Berikut penuturan Ahmad Hasan:

I Moro kembali dari pelayarannya, mungkin tertarik dengan pergaulannya dengan pedagang-pedagang muslim atau tertarik dengan tata cara kehidupan Islam di negara-negara Islam seperti Pasai dan kemudian memutuskantinggal di Gresik. Setelah selesai berguru, maka gurunya bilang lebih baik kamu kembali saja ke daerahmu sebarkan Islam. Tapi I Moro bilang, kalau hanya sendiri saya tidak sanggup. Lalu, gurunya bilang, bawalah enam orang teman seperguruanmu. Di antaranya itu ada Syekh Abdul Mannan. Tuan Andi Collang, Tuan Daeng, dan ada dua orang kita tidak ditahu namanya pergi ke perbatasan antara Barru dan Pangkep. Yang dua orang lagi tidak ditahu ke mana perginya... Ini sekitar abad XV, awal abad XVI.

Dalam pandangan penulis mengacu pada dialog I Moro dengan gurunya, seperti dituturkan di atas, I Moro tampaknya sangat berperan besar terhadap masuknya Islam di Kerajaan Banggae. Atau, bisa dikatakan, dialah peletak dasar Islam di Kerajaan Banggae. Pertama, I Moro tertarik mempelajari Islam dan kemudian memilih Islam sebagai agama barunya tanpa sepengetahuan dan persetujuan keluarga kerajaan. Kemudian. setelah resmi memeluk Islam, I Moro berinisiatif menyebarkan agama barunya ini di Kerajaan Banggae mengikuti saran gurunya. Di sini dapat dilihat. I Moro sendiri awalnya memang telah memiliki keinginan kuat untuk mengIslamkan daerahnya.

Setelah memahami Islam itulah, I Moro kembali ke Banggae ditemani enam orang sahabatnya, dikenal dengan Panrita Pilu (tujuh ulama), yang bertugas menyebarkan Islam. Adapun Panrita Pitu, antara lain, Syekh Abdul Mannan, yang bertugas menyebarkan Islam di wilayah Salabose (Parolle), Salogang, Mawasa, Naung Indu, dan Lamber Susu (Tande). Kemudian, Tuan Daeng menyebarkan Islam di wilayah Arulele dan Raja. Selanjutnya, Tuan di Colang di wilayah Totoli dan Lambe' AIlu. Dua sahabatnya yang lain berangkat ke perbatasan Barru dan Pangkep (tidak diketahui namanya). dan dua lainnya lagi yang belum dikenal namanya dan lokasi penyebaran Islamnya.

Lalu. bagaimana dengan Syekh Abdul Mannan yang disebut-sebut sebagai penganjur agama Islam pertama di Kerajaan Banggae? Menurut pandangan kami (mengacu hasi 1 wawancara dengan Ahmad Hasan), Syekh Abdul Mannan yang bergelar Tosalania' boleh dikata hanyalah "teman seperjuangan" I Moro dalam upaya penyebaran Islam di 
Kerajaan Banggae. Sebab, I Moro dan Syekh Abdul Mannan datang bersama-sama atas rekomendasi gurunya dengan tujuan menyiarkan Islam di Kerajaan Banggae. Meski begitu, eksistensi Syekh Abdul Mannan setelah Islam resmi menjadi agama di Kerajaan Banggae sangatlah besar. Setidaknya, dialah yang mempunyai ide dan gagasan membuat bendera atau lambang kerajaan bercorak Islam yang diberi nama/ Macang. Bahkan, dia sendiri yang menjahit dan mendesain bendera tersebut sehingga dipakai oleh rajaraja selanjutnya.

Awal masuknya Islam di Kerajaan Banggae tentu kontradiktif dengan masuknya penganjur Islam ke Tanah Mandar, yang selalu diawali oleh pendatang tanpa ditemani penduduk lokal. Seperti, misalnya, awal masuknya Islam di Kerajaan Balanipa diperkenalkan oleh Abdurahim Kamaluddin. Salah satu versi mengatakan, perahu Abdurrahim Kamaluddin (bergelar Tosalama di Binuang) berlabuh di pantai Tammangalle, Balanipa (versi lain menyebut di Tinambung dan berlabuh di pelabuhan Para). Penganjur Islam di Kerajaan Pamboang adalah Syekh Zakaria al-Maghribi (bergelar Puang Somba) dan Raden Mas Suryo Adilogo yang bergelar IKapuang Jawa (bangsawan Jawa). ${ }^{3}$

I Moro Daeng ta Masigi meninggal setelah memerintah Kerajaan Banggae selama 30 tahun dan dikaruniai empat anak. Setelah meninggal, ia digantikan oleh putranya, Tomatindo di Baro'bo (Raja Banggae IV). Namun, raja-raja berikutnya setelah I Moro meninggaljuga tetap menganut agama Islam. Berikut susunan Raja-raja Banggae pra dan pasca Islam:

1. I Salabose Daeng ta di Parolle

2. Daeng ta I Milanto

3. I Moro Daengta di Masigi

4. Daeng ta di Baro'bo

5. Tomatindo di Sallombo

6. Tomatindo di Selana alias Tomatindo di Pattunungang

7. Tonrawali Tomatindo di Langrisang
8. Tomatindo di Barugana

9. Pammasangi Datu Langrisang

10. Tomatindo di Pappula'

11. Tomatindo di Sikkiri'na

12. Puatta I tae'

13. Tomappelei Pattujuanna

14. Manda Pakkacoco'

15. Tomonge' Alelanna

16. INya'ring

17. Maulana Passaleppa

18. Marara Bali Puatta di Naung Indu'

19. I Sanggaria

20. I Sukkilang

21. I Ajuara Topele di Ujung Pandang

22. I Rammang Patta Lolo.

\section{Pengaruh Agama Islam dalam Dinamika Budaya Lokal}

\section{Saluran Struktur Pemerintahan}

Proses masuknya Islam di Kerajaan Banggae tidak melalui kekerasan atau peperangan. Dalam arti kata, tidak ada pemaksaan dan bentuk perlawanan dari kalangan bangsawan maupun penduduk lokal ketika Islam pertama kali dibawa dan diperkenalkan. Termasuk, ketika I Moro Daengta di Masigi terpilih menjadi Raja Banggae III dan sempat melontarkan bakal menjadikan Islam sebagai agama resmi kerajaan serta merangkap menjadi kadhi kerajaan dan Pa'Bicara Totoli. Raja Banggae II, Daeng ta di Milanto, yang merupakan ayahnya, saat itu sama sekali tidak keberatan. Perspektif kalangan bangsawan maupun penduduk mengenai I Moro sejauh ini cukup bagus. Ia dianggap"orang suci" ${ }^{34}$ sehingga apapun tindakantindakannya akan diterima dengan tangan terbuka oleh kalangan bangsawan dan penduduk Banggae.

Menurut Ahmad, pengangkatan I Moro menjadi Raja Banggae III sebenarnya tidak mendapat persetujuan salah seorang istri raja Banggae II, yang berasal dari Kerajaan Balanipa. Apalagi, I Moro pada

Muhammad Rais. Ibid... h. 51-60. Raden Mas Suryo Adilogo adalah panglima perang Kerajaan Islam Mataram pada masa Raja Sultan Agung. Sebenarnya, kedatangan Raden Mas Suryo Adilogo ke Mandar itu karena malu kepada rajanya atas kegagalannya mengusir Belanda di Batavia pada 1628-1629. Pada saat lari inilah, ia kemudian memutuskan untuk mencari gurunya, Syekh Zakaria. Awalnya, ia ke Kalimantan, lalu ke Mamuju, dan akhirnya bertemu gurunya di Pamboang. Setelah menetap di Pamboang, Mara'dia Pamboang menikahkan dengan salah seorang putrinya, Icci Puang. Ia meninggal di Galung-galung, Desa Lalampanua, Kecamatan Pamboang. Lihat juga, Syahril Kila. 2001. "Sejarah dan Budaya Masyarakat Suku Bangsa Mandar. Laporan Hasil Penelitian Sejarah dan Nilai Tradisional Sulawesi Selatan. Makassar. Balai Kajian Sejarah dan Nilai Tradisional, h., 35-36.

" "Orang suci" di sini berarti berakhlak baik. Tak heran, ketika I Moro Daeng ta Masigi memperkenalkan sekaligus menyebarkan Islam, langsung diterima oleh pihak kerajaan (wawancara dengan Kepala Museum Mandar/Majene, Ahmad, di Majene pada 21 April 2010). 
at itu belum pulang dari pelayaran. Namun, ibu I loto(berasal dari Totoli) bersikeras dan mengancam tan meminta cerai apabila bukan I Moro yang ooskat sebagai raja.

:engah kebingungan raja, I Moro tiba-tiba mcul di kerajaan sehabis pulang berlayar. - nva spontan disambut gembira kalangan termasuk raja. Selanjutnya, raja menyamnaksudnya untuk mengangkatnya sebagai kerajaan Banggae. Tapi, permintaan raja ini

- I: merta mendapat persetujuannya. I Moro media menjadi raja asalkan persyaratan yang dia

- - - jhi oleh ayahnya. Raja pun menyanggupi

- tu untuk kebaikan rakyat. Dari dialog antara

- . ayahnya, inilah pertama kalinyadikenal

- -ar.i pada Kerajaan Banggae. Selain raja tmggac. I Moro juga menjabat kadhi kerajaan dan - :toli.'- Berikut dialog mereka seperti - ir. Ahmad:

Ra/a bilang, apa itu kadhi? I Moro jawab, kadhi itu - ^eorangpemimpinyangmemimpin penyebaran $m$ dan kegiatan-kegiatan Islam. Raja bilang, un permintaanmu akan kami penuhi. Nah, - --.Mlah I moro jadi raja. Maka di situlah Islam .iisebarkan. (Wawancara dengan Kepala Mu- Iai ene. Ahmad, di Majene pada 21 April 2010).

ro tahu bahwa dengan merangkap jabatan ara'dia, kadhi kerajaan, dan Pa'bicara secara politis tentu akan memudahkannya nayebarkan Islam sebagai agama resmi kerajaan - on agama yang dianut oleh raja otomatis bakal eh rakyatnya. Setelah dinobatkan sebagai tma'a;a kerajaan Banggae menggantikan kedufanavahnya (Daeng ta I Milanto), Mara'dia I Moro •an pembaharuan dalam kerajaan dengan $\sim$ angkan prinsip adat dan kebiasaan -syarakat disesuaikan dengan syariat Islam, -aasnkmemerintahkan pembangunan dua masjid di -*• - --• Pambo'borang.

' - r.emperkokoh dan mengembangkan syiar $(\bullet \mathbf{B L}$ pembangunan masjid kerapkali diikuti pula dengan penunjukan pejabat kadhi (kali), imam (imang), serta khatib (katte), yang biasanyajabatanjabatan strategis tersebut dipilih dari kalangan bangsawan. Selain mempertahankan priveledge, penunjukan ini juga dimaksudkan agar kalangan kerajaan tetap menguasai jabatan-jabatan keagamaan serta mempertahankan unsur-unsur kepercayaan lama yang selama ini menopang kekuasan politik mereka. ${ }^{36}$

Pada awalnya, I Moro memperkenalkan Islam hanya untuk kalangan bangsawan kerajaan. Di sini, ia menginginkan semua bangsawan memeluk Islam terlebih dulu dan setelah itu barulah diperkenalkan kepada rakyatnya. Kalangan bangsawan merupakan teladan bagi rakyatnya sehingga apapun yang dilakukan kalangan bangsawan, praktis akan diikuti pula oleh rakyatnya.

Selain itu, I Moro juga selalu shalat di masjid dan menjadi imam. Karena kebiasaannya inilah sehingga nama di belakang namanya digelari Daeng $t a d i$ Masigi. ${ }^{3 \prime}$ Pada kesempatan ini juga, ia menyebarkan ajaran Islam dengan mengajar mengaji untuk kalangan bangsawan Banggae. Bahkan, karena seringnya berada di masjid, I Moro menjalankan pemerintahannya di masjid. ${ }^{38}$ Selain menjadi mara'dia, I Moro juga menjabat Pa'bicara Totoli dan Kadhi Kerajaan Banggae. Selanjutnya, bersama Syekh Abdul Mannan membuat lambang kebesaran/bendera kerajaan yang dikenal dengan nama I Mac an $g .{ }^{39}$ Replika bendera ini masih tersimpan di Museum MandarMajene.

Sebagai "orang nomor satu", saluran Islamisasi di Kerajaan Banggae tentu mengalir sangat deras. Status politik kerajaan menjadi faktor penentu proses Islamisasi itu mudah diterima dan disebarkan di kalangan rakyat karena mara 'dia mempunyai wibawa dan kharismatik di tengah masyarakatnya. Apalagi, selama jadi mara'dia, I Moro Daengta di Masigi juga dikenal arif dan bijaksana sehingga rakyat mencintainya.

nrtii i Marjanah 2007. op.cil., h. 52.
- - J Sai> 2008 op.cil.. h. 161.

tmai \& Marjanah. op.cil., h. 54.

iingan Kepala Museum Majene. Ahmad, di Kantor Museum Majene pada 21 April 2010.

irjanah. 2007. ibid, h. 77. Syekh Abdul Mannan sendiri yang membuat dan menjahit bendera Kerajaan Banggae. Wama dasar

tg keemasan dan p.ida bagian pinggirnya berwama merah mengkilap Gambar utama bendera adalah orang yang menunggang : pedang sedangkan di beberapa bagian bendera ditulisi hurul arab Menurut Ahmad, gambar orang menunggang kuda sambil : :u nielambangkan Pedang Allah seperti julukan sahabat Nabi SAW, Ali bin Abi Thalib. Bendera 1 Macang atau Macang Ali.

" . ... psi dan gambar bendera di linuir lengah oleh Syekh Abdul Qadir Jaelani yang berarti dan Tarekat Qadiriyah Namun. Ipri 2010). --arkan Islam di Kerajaan Banggae itu melalui pengajian (wawancara dengan Kepala Museum Mandar Ahmad, di Majene 
Masuknya Islam tentu berdampak pula pada perubahan struktur birokrasi kerajaan yaitu membentuk lembagakekadhianyangdipimpin oleh seorangkadhi atau kali. Bahkan, persoalan kadhi ini dipertegas pula dalam lontara Mandar (Pappasang anna Kalindaqdaq), seperti dikutip dari Ahmad Sewang dkk. (2009). Bunyi lontara tersebut adalah, "kali bali pakkana Arayang, ia manang maqurus sininna sara agamae ". (Kadhi atau kali adalah mitra kerja strategis arajang yang mengelola semua hal berkaitan masalah syariat agama). Peran lembaga ini sangat penting karena bertugas melakukan pelayanan publik pada ranah keagamaan (Islam). Lembaga Kadhi, membawahi Lembaga Syara (parewa sara') dan parewa masigi (ta'mir masjid), yang terdiri atas Capua (bertugas mendampingi kadhi dalam acara ritual adat), Jannang, Katteq (bertugas mengelola keagamaan di bidang dakwah dan khutbah), Bilal fpengurus masjid merangkap muazzin tetap), dan doja yang bertugas mengelola keuangan masjid dan sumbangan lainnya. Pejabat kadhi yang bergelar Mara 'dia Sara diangkat dan di bawah koordinasi langsung mora 'dia (raja).

Selanjutnya, kadhi juga bertanggungjawab terhadap pengembangan syiar Islam, pembinaan dan pemeliharaan rumah-rumah ibadah, melayani upacaraupacara keagamaan, mengurus jenazah, serta memutuskan dan mengatur segala hal yang berkaitan dengan Syariat Islam. Selain itu, kadhi juga merupakan penasihat dan pendamping raja dalam memutuskan perkara peradilan adat berdasarkan syariat Islam.

Selain itu, pemilihan mara'dia pun mengalami perubahan. Jika sebelum Islam masuk pemilihan mara'dia hanya didasarkan atas kehendak atau penunjukkan mara'dia (yang akan diganti), maka mekanisme tersebut berubah setelah masuknya Islam. Dalam hal ini, mora 'dia diangkat dan diberhentikan oleh hadat dan mara'dia tidak berhak memecat hadat. Mara'dia hanya berfungsi sebagai simbol kerajaan karena yang menjalankan pemerintahan dan tugas-tugas pokokpemerintahan lainnya adalah hadat. Hadat sendiri dipilih dan diangkat oleh lembaga hadat dan tokoh-tokoh masyarakat, termasuk kepala kampung. ${ }^{40}$

\section{Saluran Kultural}

Masuknya Islam berdampak besar terhadap perubahan sosial kultural masyarakat Banggae. Setelah membangun dua masjid di daerah Salabose dan
Pambo'borang di awal-awal masuknya Islam, semua yang berbau kepercayaan di luar ajaran Islam perlahanlahan mulai dihilangkan. Sebelum Islam masuk, masyarakat menganut kepercayaan animisme dan dinamisme. Menurut Ahmad Hasan, masyarakat pada waktu pra Islam masih melaksanakan ritual-ritual seperti mempercayai kalau pohon dan batu besar memiliki kekuatan yang dapat menolong mereka. Agar permohonan terkabul, masyarakat membawa sesajian kepada pohon dan batu besar yang dipercaya dapat membawa perubahan pada diri masyarakat. Membawa sesajian ke suatu tempat itu disebut massamaya. Ritual lain adalah mappasoro' (membawa sesaji di sungai dan kemudian mengalirkannya) dan mattula bala' (menyiapkan sesaji untuk menolak musibah). Dari beberapa contoh di atas tampak bahwa simbolsimbol budaya itu berangkat dari religi budaya yang tidak terdapat dalam Islam.

Selain itu, Kerajaan Banggae juga mulai melaksanakan peringatan hari-hari besar keagamaan Islam, seperti Pambaca Munuang (Maulid Nabi Muhammad SAW) yang seringkali diikuti acara khataman Alquraan, khitanan, dan sebagainya, yang semuanya disejenggarakan oleh pihak kerajaan. Khusus khatam Alquran, orang yang mengkhatamkan Alquran akan diarak keliling kampung dengan menggunakan kuda menari (saiyangpattu'du) sambil diiringi musik rebana dan di sebelah kanan dan kiri orang yang mengkhatamkan Alquran dikelilingi pula oleh beberapa anak muda mendendangkan syair (kalinda'dd). Sebelum Islam masuk, upacara tari-tarian seperti ini berfungsi sebagai penyembahan kepada dewa.

Tradisi seperti ini masih terus berlangsung sampai sekarang. Bahkan, peringatan Pambaca Munuang itu diikuti pula dengan acara khitanan dan pembacaan Kitab Barzanji di masjid, mushalla, dan rumah-rumah penduduk pada bulan Rabiul Awal. ${ }^{41}$ Khusus peringatan Maulid Nabi Muhammad Saw, pemerintah setempat seringkali memusatkan perayaannya di Masjid Syekh Abdul Mannan yang terletak di puncak Salabose, Kelurahan Pangali-Ali. Sedangkan masyarakat secara suka rela menyumbang telur ayam yang akan dipakai dalam rangka memperingati Maulid Nabi SAW itu. Di kawasan masjid ini terdapat pula makam Syekh Abdul Mannan yang hingga kini masih sering dikunjungi orang untuk berziarah atau sekadar objek wisata, baik dari masyarakat Kabupaten Majene sendiri maupun

\footnotetext{
A.M. Mandra. 2005. op.cit.. h. 56-57

"Ibrahim Abbas. 2000., op.cit.. h. 140
} 
rendatang dari luar. Sayang, masih sulit menelusuri ?:ografi dari sosok Syekh Abdul Mannan ini. Sejauh inL \ ang diperoleh dari sumber-sumber tertul is hanyalah enyebutkan kalau ia berasal dari Gresik (ada juga yang menyebut berasal dari Banten).

Vlemang, kebiasaan-kebiaasan hidup masyarakat Mandar setelah Islam masuk tampak bervariasi. Hal ini tampak pada kebiasaan-kebiasaan hidup yang rersumber dari agama yang dianut oleh masyarakat . . .:nnya masih berbaur dengan ajaran-ajaran Islam. Hasil pembauran tersebut kemudian melebur dalam budaya Mandar (ada yang sejalan dengan Istetapi adajuga yang bertentangan). Namun, terkait kebesaran, kekuasaan, dan ke-Esaan Tuhan, sejalan dengan agama Islam seperti:

$\begin{array}{ll}\text { i.Allah Taqala } & \text { : Mantapkan pemahaman syahadatmu } \\ \text { Muhammaq } & \text { : Satu Tuhan Allah semesta alam } \\ \text { paccappuanna } & \text { : Nabi Muhammad } \\ \end{array}$

Seperti pada suku bangsa Bugis-Makassar, - an masyarakat Mandar juga masih mempercayai -benda yang dianggap sakti dan keramat. Masih g mendatangi kuburan yang dianggap keramat meminta berkah dan keselamatan, serta ran benda-benda seperti batu-batuan, keris, . yang dianggap bertuah dan memiliki kekuatan

\section{- 1 u ran Perkawinan}

leski pengaruh animisme dan Hindu kerap - ai perkawinan di Tanah Mandar, namun Eizaruh Islam masih sulit dihilangkan. Yang sangat

! dari pengaruh Islam adalah adanya khutbah ir. gan) sebelum nikah, mangino (bermain-main dan ar-kejaran antara pengantin pria dan wanita) akad nikah, penggunaan real (uang Saudi ig) di dalam mahar, dan yang bertanggung sesudah nikah adalah kaum lelaki. Syarat bagi suami juga adalah tamma' topa mangaji (khatam 0-

\section{PENUTUP \\ Kesimpulan}

Islam masuk di Majene/Kerajaan Banggae pada : XVI. Penganjur agama Islam pertama di Banggae adalah Syekh Abdul Mannan, yang
h 140.
h 141.

bergeiar Tosalama di Salabose. Penyebaran Islam makin pesat ketika I Moro Daengta Masigi (Raja Banggae III) naik tahta dan segera melakukan perubahan-perubahan mendasar, baik dalam struktur pemerintahan, sosial, budaya, tradisi lokal, dan perkawinan. Di masanya, Islam ditetapkan sebagai agama resmi kerajaan, dan membangun dua masjid sebagai masjid tertua di Banggae.

Perubahan paling fenomenal terjadi pada pembatasan kekuasaan raja dan tata cara pemilihan dan pengangkatan raja. Struktrur politik kerajaan diperkaya dengan kebijakan-kebijakan yang demokratis. Raja bukan lagi penguasa otoriter, tetapi kekuasaannya berada di bawah kontrol lembaga hadat yang dipilih oleh sebuah lembaga perwakilan.

\section{Rekomendasi}

Perlunya memasukkan kurikulum muatan lokal di sekolah-sekolah mengenai 14 Kerajaan di Tanah Mandar, yakni Pitu Ba'bana Binanga dan Pitu Ulunna Salu. Hal ini perlu dilakukan karena kerajaankerajaan di Mandar merupakan kerajaan berbasis Islam, khususnya konfederasi Pitu Ba 'bana Binanga.

Pemerintah diharapkan bisa mengadakan kajian khusus mengenai penganjur agama Islam pertama di Kerajaan Banggae. Selama ini banyak versi menyebut Syekh Abdul Mannan sebagai penganjur agama Islam pertama di Kerajaan Banggae. Tapi, sayang, belum banyak yang mengetahui sosok ulama tersebut.

\section{Ucapan Terima Kasih}

Peneliti mengucapkan terima kasih kepada Kepala Balai Litbang Agama Makassar, dan teman-teman peneliti Balai Litbang Agama Makassar terutama di Bidang Kehidupan Beragama. Terima kasih yang tak terhingga kepada pihak Kanwil Kementerian Agama Provinsi Sulawesi Baratdan Kementerian Agama Kab. Majene, dan seluruh informan yang bersedia meluangkan waktu untuk memberikan informasi tentang sejarah Islam di Majene. 


\section{DAFTAR PUSTAKA}

Abbas. Ibrahim. 2000. Pendekatan Budaya Mandar. Makassar. UD Hijrah Grafika

Ahmad \& Marjanah. 2007. Sejarah dan Kebudayaan Mandar J Hid I. Sejarah Mandar dan Sejarah Perjuangan Bangsa di Kabupaten Majene. Dinas Pendidikan dan Kebudayaan Kabupaten Majene Bidang Binmudorabud Seksi Kebudayaan.

A.M Mandra. 2005. To Manurung di Mandar dalam Tinjauan Syariat Islam. Yayasan Saq-Adawang Sendana Majene bekerjasama dengan Pemerintah Kabupaten Majene.

Bodi, Muh. Idham Khalid dan Ulfiani Rahman. 2006. Bahasa Busana Mandar. Tangerang. Penerbit Nuqtah.

Idham. 2009. Dinamika dan Resolusi Konflik (Studi Tentang Konflik Sosial di Kecamatan Aralle, Tabulahan. dan Mambi (ATM) Sulawesi Barat), dalam Disertasi. Makassar: Program Pascasarjana Universitas Negeri. Tidak diterbitkan.

Kuntowijoyo. 1994. Metodologi Sejarah. Yokyakarta: PT. Tiara Wacana Yogya.

Rais, Muhammad. 2008. Etika Bisnis Wirausaha Majene-Mandar, dalam Disertasi. Makassar. Program Pascasarjana Universitas Hasanuddin. Tidak diterbitkan.

Rangkuti. Sofia-Hasibuan. 2002. Manusia dan Kebudayaan di Indonesia. Teori dan Konsep. Jakarta. Cetakan pertama. Dian Rakyat.

Salam. Rahayu. 2005. "Nilai-Nilai Budaya yang terkandung dalam Upacara Daur Hidup pada Masyarakat Mandar di Banggae Kabupaten Majene". Laporan Hasil Penelitian Sejarah dan Nilai Tradisional Sulawesi Selatan dan Tenggara. Makassar. Balai Kajian Sejarah dan Nilai Tradisional.

Sewang, Ahmad dkk., 2009. "Sejarah Islam Kerajaan Balanipa Mandar Sulawesi Barat". dalam laporan penelitian, disampaikan pada seminar hasil penelitian di Puslitbang Lektur Keagamaan Balitbang Jakarta. 